\title{
Przejmowanie dochodów podatkowych przez gminy - niektóre problemy prawne
}

\author{
Taking Tax Revenues Over Local \\ Governments - Some Legal Problems
}

Streszczenie. Prawo jednostki samorządu terytorialnego do przejmowania wpływów podatkowych może prowadzić do sporu danego samorządu z inną jednostką samorządu (na obszarze której znajduje się nieruchomość, budowla, zorganizowany zakład, miejsce zamieszkania osoby fizycznej, miejsce położenia przedmiotów opodatkowania) lub ze Skarbem Państwa, jeżeli sprawa dotyczy udziału samorządu w podatku, do którego udział ma także Skarb Państwa. Spory te nie są kwestią stosunku: organ podatkowy - podatnik. Dotyczą określenia, który samorząd ma prawo do przejęcia podatku.

Słowa kluczowe: samorząd; przejmowanie podatków; zasady prawne.

Abstract. The power of local government to take over the taxes can lead to conflicts between the local government and another local government (in whose area the property, the building, the plant, the residence and another taxable objects are located). These conflicts are not a matter of relation: the tax authority - the taxpayer. 
These problems concern the determination which of the local government has the power to take over the tax.

Keywords: local government; taking over taxes; legal principles.

\section{Uwagi wstępne}

W związku z ustawowym przekazaniem na rzecz samorządów podatków lokalnych, opłat i innych dochodów własnych pojawia się problem zasady, na której opiera się przejmowanie tych dochodów przez samorządy. Czy zasadą tą powinno być miejsce zamieszkania lub siedziby podatnika (lub płatnika), miejsce położenia przedmiotu opodatkowania, miejsce wykonywania działalności czy inne okoliczności? Czy może zachodzić krzyżowanie się uprawnień do przejęcia wpływów z danego podatku lokalnego pomiędzy różnymi samorządami lub pomiędzy jednostką samorządu terytorialnego a Skarbem Państwa? Z problemem tym wiąże się sprawa właściwości miejscowej organu podatkowego. Właściwy miejscowo w sprawach podatkowych jest na ogół ten organ podatkowy, który pobiera podatek dla swojej wspólnoty. Występują jednak sytuacje, gdy państwowe organy podatkowe pobierają podatki na rzecz gmin, a nie dla Skarbu Państwa.

Wyróżnia się trzy rodzaje uprawnień jakie mogą przysługiwać samorządowi terytorialnemu $\mathrm{w}$ zakresie podatków ${ }^{1}$. Są to uprawnienia: do przejmowania wpływów z poszczególnych podatków, do stanowienia przepisów prawnych w zakresie podatków, do administrowania w zakresie poszczególnych podatków. Kompetencja do przejmowania i wykorzystywania na własne potrzeby wpływów podatkowych pochodzących z poszczególnych podatków jest niezależna od kompetencji do stanowienia przepisów podatkowych i inna w stosunku do kompetencji w zakresie wymierzania i poboru danego podatku². Kompetencja do przejmowania

1 Por. H. Zimmermann, Allgemeine Probleme und Methoden des Finanzausgleichs, [w:] Handbuch der Finanzwissenschaft, t. IV, Tübingen 1983, s. 39-42.

2 A. Borodo, Kompetencje do przejmowania wpływów podatkowych i inne kompetencje podatkowe samorzqdów terytorialnych, [w:] W. Konieczny (red.), Ius suum quique. 
wpływów prowadzi do korzystania przez samorząd z dochodów podatkowych płynących z tytułu danego podatku (np. podatku dochodowego, podatku od spadków, podatku od nieruchomości). Dochody te są wydatkowane przez jednostkę samorządu terytorialnego na finansowanie zadań, które realizuje dana wspólnota.

Uprawnienia do przejmowania i wykorzystywania wpływów z poszczególnych podatków na potrzeby danej wspólnoty terytorialnej są regulowane w konstytucjach ${ }^{3}$ i ustawach. W Polsce przepisy właściwych ustaw ustalają, jakie podatki (w całości lub w ułamkowej części) wpływają na rzecz gminy lub innej wspólnoty terytorialnej. Przepisami tymi są ustawy podatkowe i ustawa o dochodach jednostek samorządu terytorialnego.

Kompetencja do przejmowania wpływów podatkowych związana jest z pytaniem, której jednostce samorządu terytorialnego przypada należna kwota podatku, obliczona zgodnie z przepisami prawa podatkowego? Należy bowiem zapytać, która gmina powinna uzyskać wpływy z podatku, gdy nieruchomość, gospodarstwo rolne lub leśne położone są w kilku gminach? Czy przy podatku od spadku lub darowizny zapłacony przez podatnika podatek uzyska gmina, na terenie której położone są przedmioty należące do spadku, w której ma miejsce zamieszkania spadkodawca (darczyńca) czy spadkobierca (obdarowany)? Czy podatek od czynności cywilnoprawnych przypada na rzecz gminy gdzie jest położona sprzedawana nieruchomość lub ruchomość, czy na rzecz gminy miejsca zamieszkania jednej ze stron umowy, czy na rzecz gminy, na terenie której znajduje się płatnik podatku lub organ podatkowy?

Pytania powyższe nie dotyczą wprost właściwości miejscowej organu podatkowego, zobowiązanego do załatwienia sprawy podatkowej, choć

Studia prawnofinansowe, Księga jubileuszowa dedykowana Profesorowi Wacławowi Goronowskiemu, Warszawa 2005, s. 150.

3 Art. 72-2 konstytucji Francji stanowi, że wspólnoty terytorialne korzystają ze źródeł dochodów, którymi mogą swobodnie dysponować, na zasadach określonych w ustawie. Mogą one otrzymywać całość lub część podatków wszystkich rodzajów. Art. 106 konstytucji RFN ustala, że gminom przypadają udziały we wpływach z podatku dochodowego od osób fizycznych i z podatku obrotowego oraz wpływy z podatku gruntowego, podatku od działalności gospodarczej i lokalnych podatków konsumpcyjnych. Por. W. Staśkiewicz (red.), Konstytucje państw Unii Europejskiej, Warszawa 2011, s. 289, 549. 
są z tą właściwością powiązane. Dotyczą one wskazania gminy, uprawnionej do otrzymania pobranego podatku.

\section{Regulacje w sprawie przejmowania przez gminy wpływów z opłaty skarbowej, podatku od spadków i darowizn oraz podatku od czynności cywilnoprawnych}

Ustawa z 13 listopada 2003 r. o dochodach jednostek samorządu terytorialnego ${ }^{4}$ określa sposób rozdziału pomiędzy gminy wpływów z tytułu opłaty skarbowej (art. 14), sposób przekazania gminom wpływów z podatków od spadków i darowizn (art. 15) i wpływów z podatku od czynności cywilnoprawnych (art. 16).

Zgodnie z art. 12 ustawy z 16 listopada 2006 r. o opłacie skarbowej ${ }^{5}$ organem podatkowym właściwym w sprawach opłaty skarbowej jest wójt (burmistrz, prezydent miasta), a organem właściwym miejscowo w sprawach tej opłaty jest:

1. od dokonania czynności urzędowej, wydania zaświadczenia oraz zezwolenia (pozwolenia, koncesji) - organ podatkowy (wójt, burmistrz, prezydent) właściwy ze względu na siedzibę organu lub podmiotu, który dokonał czynności urzędowej albo wydał zaświadczenie lub zezwolenie (pozwolenie, koncesję),

2. od złożenia dokumentu stwierdzającego udzielenie pełnomocnictwa lub prokury oraz jego odpisu, wypisu lub kopii - organ podatkowy (wójt, burmistrz, prezydent) właściwy ze względu na miejsce złożenia dokumentu.

Kryteriami przydzielenia dochodów z opłaty skarbowej dla danej gminy są więc: siedziba organu lub siedziba podmiotu, które: dokonały czynności urzędowej, wydały zaświadczenie, wydały zezwolenie. W przypadku pełnomocnictwa lub prokury - gmina, na której terytorium

Tekst jedn. Dz.U. z 2014 r., poz. 1115.

Tekst jedn. Dz.U. z 2012 r., poz. 1282 ze zm. 
złożono (np. w danym sądzie, w urzędzie skarbowym) dokument stwierdzający udzielenie pełnomocnictwa lub prokury.

Zapłaty opłaty skarbowej dokonuje się w kasie właściwego organu podatkowego lub na rachunek urzędu gminy (art. 8 ust. 1 ustawy o opłacie skarbowej).

Według art. 14 ust. 1 ustawy o dochodach jednostek samorządu terytorialnego wpływy z opłaty skarbowej:

1. uiszczanej gotówką, są wpłacane na rachunek budżetu gminy, na obszarze której ma siedzibę podmiot, który dokonał czynności urzędowej albo wydał zaświadczenie lub zezwolenie,

2. w pozostałych przypadkach są wpłacane na rachunek budżetu gminy, na obszarze której jest położony właściwy miejscowo organ podatkowy.

Stosownie do art. 14 ust. 2 ustawy o dochodach, jeżeli podmiotem, który dokonał czynności urzędowej albo wydał zaświadczenie lub zezwolenie, jest wójt (burmistrz, prezydent miasta) lub upoważniony przez niego podmiot, wpływy z opłaty skarbowej uiszczanej gotówką są wpłacane na rachunek budżetu tej gminy. Sformułowanie „tej gminy” dotyczy zapewne gminy, której organem jest dany wójt (burmistrz, prezydent).

Wydaje się, że wskazane wyżej przepisy ustawy o opłacie skarbowej i o dochodach samorządu nie są ze sobą sprzeczne.

W zakresie podatku od spadków i darowizn, który uregulowany jest ustawą z 28 lipca 1983 r. ${ }^{6}$, organem podatkowym właściwym rzeczowo i miejscowo jest naczelnik urzędu skarbowego. W systemie poboru tego podatku występuje także płatnik podatku - notariusz. Z podatkiem tym wiąże się sprawa przekazania wpływów z tego podatku danej (uprawnionej) gminie. Jest to podatek przydzielony gminom, chociaż pobierany jest przez naczelnika urzędu skarbowego.

Wpływy z podatku od spadków i darowizn są przekazywane gminom przez naczelnika urzędu skarbowego (na podstawie art. 15 pkt 1 do 7 ustawy o dochodach samorządu) według kilku „kluczy”: głównie według miejsca położenia nieruchomości, ale także według miejsca zamieszkania (siedziby) darczyńcy, miejsca zamieszkania obdarowanego, miejsca zamieszkania

$6 \quad$ Tekst jedn. Dz.U. z 2009 r. Nr 93, poz. 768 ze zm. 
nabywcy lub zbywcy, miejsca położenia przedmiotów spadku, miejsca zamieszkania (pobytu) spadkodawcy lub spadkobiercy.

Ustawa z 9 września 2000 r. o podatku od czynności cywilnoprawnych $^{7}$ postanawia, że właściwym rzeczowo i miejscowo w zakresie tego podatku jest naczelnik urzędu skarbowego. Obliczaniem i poborem tego podatku zajmują się także płatnicy (notariusze). Jednak podatek ten przekazany został - na mocy ustawy o dochodach samorządu - gminom. Mają one uprawnienie do przejęcia tego podatku.

Według art. 16 pkt 1 ustawy o dochodach samorządu wpływy z podatku od czynności cywilnoprawnych, których przedmiotem jest przeniesienie własności nieruchomości, prawa użytkowania wieczystego, spółdzielczego własnościowego prawa do lokalu mieszkalnego, spółdzielczego prawa do lokalu użytkowego oraz wynikających z przepisów prawa spółdzielczego: prawa do domu jednorodzinnego i prawa do lokalu w małym domu mieszkalnym są przekazywane na rachunek budżetu gminy właściwej ze względu na miejsce położenia nieruchomości. Dalsze przepisy tego artykułu przewidują inne sposoby przekazywania podatku na rzecz gminy. Od umowy spółki - na rachunek gminy na obszarze której spółka ma siedzibę. Od umowy sprzedaży przedsiębiorstwa - dla gminy, na obszarze której znajduje się siedziba tego przedsiębiorstwa. Ponadto według miejsca zamieszkania lub siedziby nabywcy, zbywcy, miejsca dokonania czynności. W końcu na rachunek budżetu gminy, na obszarze której ma siedzibę właściwy miejscowo urząd skarbowy.

Określone uprawnienia w zakresie administrowania podatkiem od czynności cywilnoprawnych, podatkiem od spadków i darowizn i podatkiem dochodowym opłacanym w formie karty podatkowej przyznaje jednak ustawa o dochodach samorządu wójtom, burmistrzom prezydentom miast. Chodzi tu o przewidziane w art. 18 ust. 2 uprawnienie do wyrażenia przez gminny organ podatkowy zgody na zastosowanie - przez naczelnika urzędu skarbowego - ulg podatkowych: umorzenia należności podatkowej, odroczenia terminu zapłaty, rozłożenia należności na raty.

$7 \quad$ Tekst jedn. Dz.U. z 2010 r. Nr 101, poz. 649 ze zm. 
Rozporządzenie Ministra Finansów z 22 sierpnia 2005 r. w sprawie właściwości organów podatkowych ${ }^{8}$ nie wprowadza regulacji dotyczących przekazywania wpływów podatkowych na rzecz gmin. W kontekście omawianych tu zagadnień wskazać trzeba na $\S 7$ rozporządzenia, który ustala właściwość miejscową organów podatkowych w sprawach podatku od spadków i darowizn. Wskazuje on jako właściwego naczelnika urzędu skarbowego, w którego zasięgu działania położona jest nieruchomość, a także inne okoliczności wpływające na tę właściwość, tj. miejsce zamieszkania lub pobytu spadkodawcy bądź nabywcy.

\section{Niektóre ustawy podatkowe a przejmowanie wpływów podatkowych przez gminy}

Ustawa o dochodach jednostek samorządu nie określa, która gmina jest uprawniona do uzyskania podatku, jeżeli wpływy dotyczyć będą karty podatkowej, podatku od nieruchomości, podatku rolnego, leśnego, od środków transportowych. Sprawy te należy więc zbadać na tle innych ustaw.

Ustawa z 12 stycznia 1991 r. o podatkach i opłatach lokalnych ${ }^{9}$ sta- $^{-}$ nowi w art. 1c, że organem podatkowym właściwym w sprawach podatków i opłat unormowanych w tej ustawie jest wójt (burmistrz, prezydent miasta). Ustawa ustala konstrukcję dwóch podatków lokalnych: podatku od nieruchomości i podatku od środków transportowych, a także czterech opłat lokalnych.

Według art. 6 ust. 7 ustawy podatek od nieruchomości za rok podatkowy od osób fizycznych ustala w drodze decyzji organ podatkowy właściwy ze względu na miejsce położenia przedmiotów opodatkowania. Tak samo sprawę właściwości miejscowej organu podatkowego ustala ust. 9 tego artykułu, jeśli chodzi o podatek od nieruchomości obciążający osoby prawne i jednostki organizacyjne (organ właściwy ze względu na miejsce położenia przedmiotów opodatkowania).

Dz.U. Nr 165, poz. 1371 ze zm.

Tekst jedn. Dz.U. z 2014 r., poz. 849. 
Istotne dla przejmowania przez gminę podatku od nieruchomości i związanej z tym właściwości miejscowej organu jest uregulowanie art. 4 ust. 9 ustawy odnoszące się do opodatkowania budowli położonej w dwóch lub większej liczbie gmin. Według tego przepisu wartość części budowli położonych w danej gminie, w przypadku budowli usytuowanych na obszarze dwóch lub więcej gmin, określa się proporcjonalnie do długości odcinka budowli położonego na terenie danej gminy. Do przejęcia podatku (oraz do jego wymierzania) właściwa jest więc ta gmina, na obszarze której znajduje się odcinek (fragment) budowli, usytuowany na jej terenie.

Według art. 9 ust. 7 ustawy o podatkach i opłatach lokalnych organem właściwym w sprawach podatku od środków transportowych jest organ podatkowy, na którego terenie znajduje się miejsce zamieszkania lub siedziba podatnika, a w przypadku przedsiębiorstwa wielozakładowego lub podmiotu, w którego skład wchodzą wydzielone jednostki organizacyjne - organ podatkowy, na terenie którego znajduje się zakład lub jednostka posiadająca środki transportowe podlegające opodatkowaniu. Podatek przypadać więc powinien gminie, na terenie której występuje: miejsce zamieszkania lub siedziba podatnika, albo na terenie której występuje zakład lub jednostka organizacyjna posiadająca środki transportowe. Wspomniany przepis stanowi też, że w przypadku współwłasności środka transportowego organem właściwym jest organ podatkowy (wójt, burmistrz, prezydent) odpowiedni dla osoby lub jednostki organizacyjnej, która została wpisana jako pierwsza w dowodzie rejestracyjnym pojazdu.

Ustawa z 15 listopada 1984 r. o podatku rolnym ${ }^{10} \mathrm{w}$ art. 6a stanowi, że organem podatkowym właściwym w sprawach podatku rolnego jest wójt (burmistrz, prezydent miasta). Podatek ten dla osób fizycznych ustala w drodze decyzji organ podatkowy właściwy ze względu na miejsce położenia gruntów. Osoby prawne i jednostki organizacyjne także zobowiązane są do uiszczenia podatku rolnego na rzecz tej gminy, w której położone są grunty.

10 Dz.U. z 2013 r., poz. 1381 ze zm. 
Ustawa z 30 października 2002 r. o podatku leśnym ${ }^{11}$ stanowi, że organem podatkowym właściwym w sprawach podatku leśnego jest wójt (burmistrz, prezydent miasta), a zasadą poboru podatku leśnego na rzecz danej gminy jest miejsce położenia lasu (tj. położenie lasu lub lasów $\mathrm{w}$ danej gminie). Wynika to $\mathrm{z}$ art. 6 ustawy.

Dochodem gminy pobieranym przez naczelnika urzędu skarbowego jest karta podatkowa, określona przepisami ustawy z 20 listopada $1998 \mathrm{r}$. o zryczałtowanym podatku dochodowym od niektórych przychodów osiąganych przez osoby fizyczne ${ }^{12}$. Zgodnie z art. 29 ust. 3 tej ustawy właściwym miejscowo w sprawie karty podatkowej jest naczelnik urzędu skarbowego według miejsca położenia zorganizowanego zakładu wskazanego w zgłoszeniu do ewidencji działalności gospodarczej. W razie niespełnienia zgłoszenia lub bez posiadania zorganizowanego zakładu jest to organ właściwy według miejsca zamieszkania podatnika lub siedziby spółki cywilnej (lub miejsca zamieszkania jednego ze wspólników). Jeżeli występuje kilka zorganizowanych zakładów (i właściwych jest kilku naczelników urzędów skarbowych), właściwość miejscową ustala się według miejsca wskazanego przez podatnika jako siedziba działalności.

Przepisy nie wskazują, jakiej gminie naczelnik urzędu skarbowego powinien przekazać pobrany podatek dochodowy w formie karty podatkowej. Wydaje się, że będzie to gmina, na terenie której jest położony zorganizowany zakład, na obszarze której jest miejsce zamieszkania podatnika, siedziba spółki lub miejsce zamieszkania jednego ze wspólników, albo gmina, na terenie której jest siedziba działalności, wskazana przez podatnika. Sądzę, że przekazywanie przez naczelnika urzędu skarbowego wpływów z karty podatkowej na rzecz danej gminy nie jest wyraźnie uregulowane. Może prowadzić do dowolności lub różnych sposobów przekazywania tych wpływów. Dodatkowe komplikacje dotyczące przekazania wpływów z karty podatkowej na rzecz gminy wystąpić mogą w razie zmiany właściwości miejscowej organu podatkowego w trakcie roku podatkowego.

11 Tekst jedn. Dz.U. z 2013 r., poz. 465.

12 Dz.U. Nr 144, poz. 930 ze zm. 


\section{Udziały gmin w podatkach dochodowych}

Samorządy mają prawo przejmowania udziałów w dwóch podatkach dochodowych: w podatku dochodowym od osób fizycznych i w podatku dochodowym od osób prawnych.

Udział gminy we wpływach z podatku dochodowego od osób fizycznych oblicza ministerstwo finansów. Bierze pod uwagę należne podatki od osób fizycznych zamieszkałych na obszarze gminy. Konstrukcję udziału (który wynosi ok. 38\% podatku) szczegółowo określa art. 9 ustawy o dochodach samorządu.

Przejmowanie wpływów z tytułu udziału gmin w podatku dochodowym od osób prawnych reguluje ustawa o dochodach samorządu w art. 10. Gminy mają udział w tym podatku (wynoszący 6,71\%) od osób prawnych i jednostek organizacyjnych posiadających siedzibę na terenie gminy. Wspomniana część podatku dochodowego jest przekazywana na rachunek gmin przez urzędy skarbowe.

Niektóre osoby prawne lub jednostki organizacyjne mają zakłady lub oddziały położone w innych gminach niż te, gdzie znajduje się siedziba. W takiej sytuacji gminy, na obszarze których znajduje się oddział bądź zakład, otrzymują odpowiednio obliczony udział. Dochody z tytułu udziału są przekazywane do budżetów tych gmin, na których obszarze położony jest ten zakład (oddział), proporcjonalnie do liczby osób w nich zatrudnionych na podstawie umowy o pracę. Naczelnik urzędu skarbowego przekazuje gminom, na których terenie podatnicy posiadają zakłady (oddziały), należne im dochody nie później niż w terminie 14 dni od dnia, w którym podatek wpłynął na rachunek urzędu skarbowego.

$\mathrm{Z}$ udziałem jednostek samorządu terytorialnego w podatku dochodowym od osób fizycznych lub prawnych łączy się uprawnienie samorządu do wpłaty udziału wówczas, gdy Skarb Państwa, reprezentowany przez właściwy organ (Ministra Finansów, naczelnika urzędu skarbowego) nie przekazuje kwoty należnego udziału w podatku lub powstaje spór pomiędzy jednostką samorządu terytorialnego a właściwym organem Skarbu Państwa, czy dana kwota udziału w podatku powinna być przekazana ${ }^{13}$.

A. Borodo, Samorzqd terytorialny. System prawnofinansowy, Warszawa 2012, s. 91 i n. 
Skarb Państwa i gmina mają takie samo prawo do swoich udziałów w podatku dochodowym od osób fizycznych i od osób prawnych. Obie te wspólnoty mają osobowość prawną, dysponują odrębnym majątkiem, wykonują zadania publiczne w imieniu własnym i na własną odpowiedzialność. Gmina nie jest organizacyjnie podporządkowana Ministrowi Finansów lub urzędowi skarbowemu, stosunki pomiędzy tymi podmiotami regulowane są ustawami, a spory, które pojawią się na tle tych regulacji, powinny być badane w postępowaniu sądowym.

Zobowiązanie do przekazania przez Skarb Państwa należnej gminie kwoty może być ocenione jako zobowiązanie cywilnoprawne powstałe na podstawie ustawy. Jeżeli Skarb Państwa nie przekazuje należnego udziału, to gmina ma roszczenie do Skarbu Państwa o wypłatę należnej kwoty, tj. o wykonanie zobowiązania, którego źródłem jest sama ustawa.

\section{Uwagi końcowe}

Uprawnienie jednostki samorządu terytorialnego do przejmowania wpływów podatkowych może prowadzić do sporu danego samorządu z inną jednostką samorządu (na której obszarze znajduje się nieruchomość, budowla, zorganizowany zakład, miejsce zamieszkania lub pobytu, miejsce położenia przedmiotów) lub ze Skarbem Państwa, jeżeli sprawa dotyczy udziału samorządu w podatku, do którego udział ma także Skarb Państwa. Spory te nie są w zasadzie kwestią stosunku: organ podatkowy - podatnik. Dotyczą określenia, który samorząd ma prawo do przejęcia podatku.

Ewentualny spór dotyczy pytania, której jednostce samorządu przysługuje podatek lub jaka kwota stanowi udział w podatku, jeżeli uprawnienia do należności podatkowej mogą być przyznane kilku uprawnionym samorządom, nie jest jasne, który z nich ma przejąć wpływy podatkowe, lub jest sporne, czy udział samorządu w podatku państwowym został prawidłowo ustalony.

Należy przyjąć odpowiednie rozwiązanie dotyczące przekazywania gminom wpływów z podatku dochodowego opłacanego w formie karty podatkowej, a także rozważyć, czy organem podatkowym dotyczącym tego podatku nie powinien być organ gminy. 
Andrzej Borodo

\section{Bibliografia:}

Borodo A., Kompetencje do przejmowania wpływów podatkowych i inne kompetencje podatkowe samorzq̨ów terytorialnych, [w:] W. Konieczny (red.), Ius suum quique. Studia prawnofinansowe. Księga jubileuszowa dedykowana Profesorowi Wacławowi Goronowskiemu, Liber, Warszawa 2005, s. 149-160.

Borodo A., Samorzq̨ terytorialny. System prawnofinansowy, LexisNexis, Warszawa 2012.

Staśkiewicz W. (red.), Konstytucje państw Unii Europejskiej, Wydawnictwo Sejmowe, Warszawa 2011.

Zimmermann H., Allgemeine Probleme und Methoden des Finanzausgleichs, [w:] Handbuch der Finanzwissenschaft, t. IV, Tübingen 1983. 